Bente Aamotsbakken, professor i tekstvitenskap

Institutt for språkfag

Høgskolen i Vestfold

Norunn Askeland, professor i norskdidaktikk

Institutt for språkfag

VISIONS

Conference

2011:

Teaching

Høgskolen i Vestfold

\title{
Literacy i naturfag og fysikk. Hva kreves av grunnleggende ferdigheter?
}

\begin{abstract}
Artikkelen drøfter lcereplanens vekt på grunnleggende ferdigheter og argumenterer for at grunnleggende ferdigheter lesing og skriving kan studeres som én ferdighet: literacy. Lcererens rolle blir ansett å vcere avgjørende for innlering og styrking av denne ferdigheten, også i fag som naturfag og fysikk. Funnene fra to større forskningsprosjekter finansiert av Forskningsrådet ligger til grunn for valg av to case som vi presenterer og analyserer. I prosjektene har lesing og skriving vært undersøkt, og vi har i begge prosjekt sett på sammenhengen mellom de to ferdighetene. Den er så tett at vi derfor argumenterer for én grunnleggende ferdighet: literacy. Muntlighet inntar en viktig plass $i$ undervisningen, og i artikkelen er det scrlig lærerens rolle som modellerer og mediator som knyttes til betydningen av muntlig kommunikasjon.
\end{abstract}

\section{Innledning}

I to forskningsprosjekter om henholdsvis lesing og skriving i naturfag og fysikk fant vi at lesing er uløselig knyttet til skriving og vice versa. Vi har observert elever på flere trinn i grunnskolen og videregående skole og sett at de skriver under lesingen og leser tekster på papir og skjerm under skriving. I denne artikkelen stiller vi spørsmålet om hvilken rolle lesing og skriving spiller for utviklingen av naturfaglig literacy (scientific literacy), og vi hevder at lesing og skriving kan studeres som én kompleks ferdighet. Videre vil vi argumentere for lærerens betydning som modell og mediator for utvikling av literacy i de to fagene.

Det er viktig å knytte lesing og skriving sammen som analyseobjekt fordi vi da får øye på det som utgjør det som ofte omtales som literacy. Det er ikke noe fullgodt norsk begrep som har kommet til erstatning for termen literacy, men vi definerer literacy som kombinasjonen av lesing og skriving. Skriftkyndighet er blitt foreslått som norsk term uten at den har vunnet gjenklang og erstattet det engelske begrepet. Imidlertid er skriftkyndighet ikke så dumt som begrep fordi 
lesing handler om avkoding av skrift, og skriving handler om å beherske skrift. Man må være kyndig eller ha kunnskap om hvordan man leser og hvordan man senere kan skape egne tekster på bakgrunn av hva andre har skrevet. ${ }^{1}$

I forskningslitteraturen har det vært vanlig å studere lesing og skriving hver for seg. Leseforskningen er omfattende og studerer hvordan lesekoden knekkes, ulike lesemetoder, lesing i det videre skoleløpet og lesing av forskjellige typer tekster (Bråthen, 2007; Reichenberg, 2007, Pressley, 2003). Skriveforskningen har konsentrert seg om prosessorientert skriving, skriving i en rekke sjangrer og skriving i ulike profesjoner og utdanninger (Smidt, 2010; Smidt, Solheim \& Aasen, 2011; Bazermann \& Prior, 2004). Videre har både lese- og skriveforskningen rettet seg mot hvordan minoritetskulturelle elever i skolen leser og skriver (Hvistendahl, 2009; Hvistendahl \& Roe, 2004; Kulbrandstad, 1997, 2003; Engen \& Kulbrandstad, 2004; Bakken, 2009). Imidlertid er det klart at både leseforskning og skriveforskning er literacy-orienterte studier, der lesing av tekst, avkoding, interpretasjon og skriving inngår. Læreplanen (Kunnskapsløftet) har som intensjon å knytte fag i skolen sammen ved hjelp av fem ferdigheter som skal være grunnleggende for undervisningen. Lesing og skriving er definert som to av de fem ferdighetene, og vi vil hevde at de ofte utgjør én sammenknyttet ferdighet. Til denne ferdigheten knytter de andre tre ferdighetene: muntlig, matematisk og digital ferdighet, seg. Med andre ord er lesing-skriving, eller som vi benevner det, literacy, overordnet de tre andre ferdighetene. Det må føyes til at muntlig ferdighet inntar en egen rolle fordi oppbyggingen av literacy hos elever i skolen er svært avhengig av muntlige forklaringer og annen muntlig tilrettelegging. Videre er muntlig ferdighet den basale ferdigheten som barn først tilegner seg, selv om læreplanen ikke nevner den som den første. Muntlig ferdighet er en forutsetning for innøving av både lesing og skriving. Språket er mediet som brukes både i muntlig tale, det vi leser og det vi skriver.

Matematisk ferdighet er også avhengig av literacy fordi vi må kunne lese og forstå en matematisk formel og anvende skrift for å besvare en oppgave. Vi kan snakke om matematisk literacy (numeracy) som består i å beherske tall og figurer i kombinasjon for å kunne regne ut og finne løsninger på matematiske problemer (se for eksempel Cokely, Galesic, Schulz, Ghazal \& GarciaRetamero, 2012) ${ }^{2}$. I læreplanen kommer digital ferdighet som nummer fem. De fire første ferdighetene har alltid vært viktige å beherske og utvikle i løpet av skolegangen. Vi vil i denne artikkelen argumentere for at digitale medier ikke spiller noen hovedrolle for opplæringen i og beherskelsen av literacy, men at mediene i flere tilfeller har viktige støttefunksjoner. Denne argumentasjonen er basert på våre funn i de to prosjektene og kan ikke verken motsi eller bekrefte funn i andre forskningsprosjekter.

Derimot har vi i våre prosjekter observert at læreren er svært viktig for å gjøre elevene kompetente. Med andre ord er læreren en nøkkelperson når det gjelder å utvikle literacy (se for eksempel Molander \& Terum, 2008; Nordahl, 
2010; Hattie, 2009). Det er læreren som legger til rette for forståelsen av fagbegrep og sammenhenger, det er han eller hun som velger ut fra lærebøkenes og nettstedenes tekster, og det er også læreren som har kunnskap om hva som er viktig å lære og hvilke sjangrer elevene trenger å få kunnskaper om. Forholdet lærer-elev er asymmetrisk, og våre observasjoner og intervjuer har vist at læreren fungerer som den viktigste læringsressursen for elevene når de skal lære nytt stoff i naturfag/fysikk.

\section{Nødvendigheten av literacy}

Kjell Lars Berge har benevnt læreplanen (Kunnskapsløftet) som en literacyreform, og det er et resonnement vi slutter oss til (Berge, 2012; Maagerø, Halliday \& Berge, 2005). Planverket ble ansett som nyskapende da det ble lansert i 2006, og selv om noen fag nå er under revidering, vil prinsippet om de grunnleggende ferdighetene bli beholdt. Det nye ved planverket ligger i at fire ferdigheter: lesing, skriving, muntlighet og regning, skal gjelde for alle fag. I tillegg er som nevnt digital ferdighet føyd til. I tidligere planverk har de fire nevnte ferdighetene ligget bak mye av det som er blitt tematisert, men det nye med Kunnskapsløftet er at ferdighetene er skrevet fram og skal øves i alle skolens fag (Skaftun, 2006). Tidligere var for eksempel lesing og skriving nærmest å betrakte som et norskfaglig emne (Madsen, 1999), mens lesing og skriving nå skal foregå i naturfag, matematikk, kroppsøving osv. Det legger et større ansvar på den enkelte lærer og fordrer samarbeid på tvers av faggrenser og fagseksjoner i skolen.

Det er blitt nødvendig å beherske literacy for alle lærere og være oppmerksom på forpliktelsen til å trene elevene i lesing av fagtekster og skriving i faglige sjangrer. Literacy er derfor noe som lærere har ansvar for å gi opplæring i, og som er en forutsetning å beherske dersom man skal lykkes i samfunnet vårt både under skolegangen og senere i profesjonslivet. Literacy er ofte knyttet til lesing, men da er det et bredt lesebegrep som er ment; et begrep som knytter sammen lesing og skriving og inkluderer visuelle, auditive og verbale uttrykk. En etter hvert klassisk definisjon av literacy stammer fra forskeren David Barton som i 1994 sa følgende:

Literacy is a fairly recent English word and its meaning is being extended. I am using the term to cover new, broader views of reading and writing, and that is how it is being used in several disciplines and in phrases like emergent literacy, used in education. (Barton, 1994, s. 19)

Barton anser uten videre lesing og skriving som å tilhøre literacy-begrepet, og han peker også på begrepets utvidelse. I dag omfatter literacy foruten lesing og skriving av verbaltekster også evnen til å lese og tolke visuelle og andre kulturelle uttrykk (Eriksson, 2009; Drotner, 1999; Kress \& van Leeuwen, 1996, 
2001; Engebretsen, 2007; Otnes, 2009). På grunn av begrepsutvidelsen har underkategorier av literacy grodd fram, slik som medie-literacy, visuell literacy, økonomisk literacy o.a. I vår sammenheng kan vi tale om naturfaglig literacy eller 'scientific literacy' som omfatter den basis av allmennkunnskap som anses nødvendig for å delta på meningsfylt måte i samfunnet (Sjøberg, [2004] 2009). Like fullt handler også denne formen for literacy om det å beherske lesing og skriving i faget. Vi vil derfor argumentere for at det er samme literacy-begrep som gjelder for eksempel i naturfag som i en rekke andre skolefag, men at naturfaglig literacy er knyttet spesifikt til naturfagets fagtekster og sjangrer. Det samme vil gjelde for matematisk literacy, for literacy i fremmedspråksundervisning osv.

Det har vært ført en diskusjon om både literacy-begrepet i sammenheng med nærliggende begreper som kompetanse, dannelse og ferdigheter i løpet av de siste ti årene. Spesielt etter at Kunnskapsløftet ble innført, ble diskusjonen heftigere. For DeSeCo (The OECD's Definition and Selection of Competencies) benyttet begrepet key competencies som skal sette unge mennesker i stand til å mestre samfunnets utfordringer. De må kunne delta i demokratiet, tenke og handle selvstendig og samtidig i samhandling med andre, og de må kunne bruke tilgjengelige multimodale ressurser, tekster og teknologier. Nøkkelkompetansene har sammenheng med diskusjonen av dannelsesbegrepet som har vært ført i Norden de siste årene (Penne, 2001; Skaftun, 2006; 2009; Aase, 2005a, b). Denne diskusjonen har gått parallelt med en diskusjon i den engelskspråklige verden om begrepet literacy. Et innovativt literacy-begrep omtales for eksempel i PISA-programmet:

[PISA's] innovative "literacy" concept concerned with the capacity of students to analyse, reason and communicate effectively as they pose, solve and interpret problems in a variety of subject matter areas; (DeSeCo, 2005; s. 3)

Her er det tale om en type literacy som ser ut til å overskride lesing og skriving alene. Det handler i utvidet mening om å kunne orientere seg i større tekstmasser samt å kunne "bevege seg i tekster” og ”å sette tekster i bevegelse” (Liberg, 2004). Likevel vil vi hevde at literacy som grunnleggende ferdighet når det oppøves innenfor faglige rammer, vil sette elever i stand til også å beherske større mengder tekst.

\section{Forsking om literacy i naturfag og fysikk}

Naturvitenskapelige fag som naturfag i grunnskolen og fysikk i videregående skole skal lære elevene om systemer og sammenheng i prosesser i naturen. Å lese og skrive i naturfag og fysikk vil si å kunne beherske en rekke naturvitenskapelige fagbegreper som på papiret kan oppleves som abstrakte og 
krevende. Ofte dreier det seg om fagbegreper som tilhører forskningslitteraturen og som må adapteres til et nivå som skaper mening for yngre elever. Prosjektet "Elever som forskere i naturfag" har studert utforskende arbeidsmåter i naturfag, der skriving i fagets sjangere er blant arbeidsmåtene i kunnskapsoppbyggingen. Literacy i naturfag vil følgelig i dette prosjektet handle om å tilegne seg fagets sjangere. Om laboratorierapporten sies det at den er en "veletablert sjanger i norsk skole” (Knain \& Kolstø, 2011, s. 37), og at

\footnotetext{
En kunne tenke seg at hver av de ulike teksttypene som utgjør laboratorierapporten, ble øvd hver for seg: problemformulering (spørsmål), gjennomføring (fortelling), resultat (beskrivelse) og konklusjon (argumentasjon). Men forståelsen av hvert enkelt av dem avhenger av hvordan de inngår i den helheten som laboratorierapporten er, og den praksis som laboratorierapporten er del av. Å mestre naturfag handler i stor grad om å ha internalisert fagets sjangre [...]. (Knain \& Kolstø, 2011, s. 37f.)
}

Rapportsjangeren er den elevene i naturfag oftest møter enten de leser naturfaglige fagtekster eller skal besvare oppgaver skriftlig. Kolstø (2009) skiller mellom beskrivelse av objekter og forklaring av prosesser. Han nevner videre begrepsoversikt som beskriver en klasse av objekter. Han skiller også mellom prosedyretekst som beskriver hvordan en aktivitet skal gjennomføres med formål, utstyr og trinnvis gjennomføring, og eksperimentrapport, som er delt i introduksjon, metode, resultater og diskusjon. Eksperimentrapporten vil trolig samsvare med laboratorierapporten som ovenfor beskrives som en "veletablert sjanger”. Elever i naturfag møter det som Kolstø beskriver som prosedyretekst i sine lærebøker og læremidler, mens de trenes i å skrive det som kan sammenliknes med eksperimentrapporten. Læremidlene gir eksempler på fagets sjangere i tillegg til at oppgaver finnes i stort antall for å trene skriving i de samme sjangrene (Maagerø \& Skjelbred, 2010).

Literacy i naturfag diskuteres også i prosjektet "Forskerføtter og leserøtter" der aktiviteter som lesing, eksperimentering, snakking, felting og skriving ses på som viktige arbeidsmåter for å oppøve grunnleggende ferdigheter (Ødegaard \& Frøyland, 2010). Også dette prosjektet setter naturfaglige fagtekster i sentrum for å forstå og beherske en naturfaglig diskurs, og det legges vekt på å skape varierte læringsaktiviteter. Et prosjekt som har studert læringsprosesser i kjemiklasserom i Sverige og den svensktalende delen av Finland, har vektlagt variasjon både i læringsressurser og arbeidsaktiviteters betydning for optimal læring (Danielsson, 2011). Modeller i lærebøker kan være så abstrakte at elever ikke har en mulighet for å forstå dem uten hjelp fra en lærer. Danielsson viser hvordan en læringsprosess legges opp med trinnvise forklaringer der lærerens forklaringer og gester spiller en stor rolle for elevers læring.

Nyere lærebøker i naturfag og andre fag er multimodale og multimedialt orienterte (Selander \& Kress, 2010; Holm Sørensen et al., 2010; Beetham \& Sharpe, 2007). Forlagene har et krav på seg til å produsere nettsider og nettsteder for de læreverkene de markedsfører. Det er en forutsetning at lærebok 
og nettressurser brukes samtidig, og at de skal utfylle hverandre. Vi kan ikke lenger snakke om sammenhengende lærebøker, men om tekstkomplekser og avanserte medieprodukter, der det er stor fare for fragmentering, og der lærerens rolle som leselærer og rådgiver blir viktigere enn noen gang (Askeland \& Vareberg, 2010). Både elever og lærere har nå tilgang til flere læringsressurser på grunn av den voksende graden av multimodalitet og multimedialitet (BernersLee, 1999; Burn, 2007). Samtidig er kravene skjerpet fordi de nye mediene krever kompetanse slik at de blir brukt mest mulig optimalt. Vi kan si at hele læringssituasjonen har gjennomgått dramatiske endringer etter at digitale læringsmedier er blitt så vanlige i utdanningssystemet (Vannini, 2009). Endringene består blant annet $\mathrm{i}$ at det finnes en rekke muligheter for å være kreativ og innovativ samtidig som mediene stiller krav til sine brukere. Behovet for å beherske literacy er derfor skjerpet i en tid der teksttilgangen og informasjonsmengden stadig øker. Det kan se ut til at noen elever ser på læringsmediene som interessante "dingser", men ikke kan se at de er reelle redskaper for læring. Dette igjen innebærer at de bare ser noen av de potensialene som er lagt inn i de digitale mediene (Cerratto Partgman \& Wærn, 2003). Med opplæring i literacy innenfor faglige rammer vil likevel elever ha muligheter til å både dra nytte av nyere mediers potensial og vurdere tekstflommen i mediene kritisk.

\section{Metode og utvalg av case}

Våre to forskningsprosjekter er bygget på kvalitative metoder med flere casestudier (Postholm, 2005; Postholm \& Moen, 2009). Vi har foretatt fokuserte og systematiske observasjoner i flere klasserom (Adler \& Adler, 1994), men her vil vi konsentrere oss om to av dem. Det første er et naturfagsklasserom på femte trinn på en større byskole på sentralt østland. Skolen har innpå $80 \%$ minoritetskulturelle elever. Det andre er et fysikk-klasserom på en videregående skole i en mindre by på Østlandet. Eksemplet fra fysikk-klasserommet hører til tredje årstrinn, studiespesialiserende program (Fysikk 2). Vi har fulgt denne klassen over to år slik at vi også har data fra andre trinn (Fysikk 1). For begge skoler har vi observert økter på 2 ganger 45 minutter; for grunnskolen totalt fem økter og for videregående tre økter på andre trinn og fem økter på tredje trinn. Vårt fokus i observasjonene i begge prosjekter har vært kombinasjonen av leseog skriveaktiviteter, og vi har ført refleksjonssamtaler i etterkant av hver økt. Siden vi har observert i par på to forskere, har disse samtalene kunnet skjerpe fokus og unngå å rette oppmerksomheten mot aktiviteter som ligger utenfor rene lese- og skriveaktiviteter. I etterkant av observasjoner og refleksjonssamtaler har vi skrevet daterte observasjonslogger som er sammenholdt med våre notater under observasjonene i klasserommet (feltnotater). For grunnskolen har vi benyttet lydopptak og feltnotater, mens vi for videregående skole også har brukt 
videofilming. For intervjuene har vi for begge skoleslag basert oss på lydopptak og videofilming. Intervjuene for grunnskolen ble gjort i par, mens vi i videregående skole har benyttet fokusgruppeintervjuer (Kvale \& Brinkmann, 2009). I intervjuene har vi spurt elevene om deres lese- og skriveaktiviteter. Vi har også intervjuet lærerne om typiske arbeidsmåter i faget. Videre har vi analysert alt materiale fra observasjoner og intervjuer og trukket ut to case som vi i det følgende vil beskrive og analysere. Vårt valg av case er truffet ut fra den betraktning at det handler om typiske undervisningssituasjoner som er representative for de to materialkorporaene. Vi har i analysearbeidet søkt å finne mønstre som er repetitive og som kan gi oss forståelse for hva som kjennetegner lesing og skriving i naturfag og fysikk og dermed hva som karakteriserer naturfaglig literacy (Norris \& Phillips, 2003).

I observasjonene har vi hatt spesiell oppmerksomhet på samspillet mellom dialoger i klasserommet og bruk av ulike læringsressurser. I prosjektene for øvrig har vi anvendt ulike analytiske tilganger til våre materialkorpora. For å analysere læringsressursene som har vært i spill i de klasserommene vi har observert, har vi anvendt både tekstlingvistiske, retoriske og metaforteoretiske analysemetoder (Kjeldsen, 2006; Kjeldsen \& Grue, 2011; Steen, 2011; Vagle, Sandvik \& Svennevig, 1993). For å studere elevers skriveprodukter, da særlig i fysikk på videregående, har vi i tillegg anvendt multimodalitetsanalyse (Lemke, 2000; Løvland, 2006; Kress, Jewitt, Ogborg \& Tsatsarelis, 2001; Kress, 2010). Literacy events i begge prosjekter er blitt analysert ut fra et sosialkonstruktivistisk syn på læring (Barton, 1994; Barton \& Hamilton, 1998). Begrensningene i våre prosjekter ligger i at de representerer kvalitative studier som ikke tillater å trekke slutninger ut over det som er observert, analysert og reflektert over innenfor prosjektrammene. De to casene representerer eksempler på sammenflettede lese- og skriveaktiviteter kombinert med effektiv bruk av læringsressurser (Stake, 1995; Blatter \& Blume, 2008).

\section{Naturfaglig literacy på femte trinn}

Femteklassen vi besøkte, hadde 25 elever, og de skulle introduseres for emnet geologi. I klasserommet fantes forskjellige gjenstander og læringsressurser som for eksempel en steinsamling i tillegg til mange oppslagsverk, lærebøker, pc-er, arbeidsbøker, arbeidsark med oppgaver og øvelser, tegnemateriell o.a. Elevene hadde dessuten tilgang til datarommet som lå i umiddelbar nærhet til klasserommet. I begynnelsen av geologiøkta bad læreren elevene om å lukke øynene og tenke på steiner eller fjell. Etter en stund spurte hun elevene om hva de hadde tenkt. En av guttene sa: "Jeg ser et fjell i Kosovo. Bestefaren min fortalte oss ofte historier om dette fjellet." En annen gutt sa: "Jeg ser vann og bølger og en flott sandstrand.” I et etterfølgende intervju med læreren fortalte hun at ett av hennes arbeidsprinsipper var å introdusere fagbegreper ved å spille 
på elevenes aktive kunnskaper og tidligere erfaringer enten de var fra Norge eller et annet opprinnelsesland. Utsagnet om fjellet i Kosovo virket identitetsbekreftende for den albanske eleven og utvidet perspektivet geografisk for hele klassen. Tidligere forskning har vist at minoritetskulturelle elever trenger bekreftelse både i forhold til sitt nye hjemland med dets språk og kultur og sitt tidligere hjemland og dets kultur (Hvistendahl, 2001, 2007; Hvistendahl \& Roe, 2004; Cummins, 2004).

Lenger ut i økta skrev læreren en rekke fagtermer på white-board - termer som alle relaterte seg til kapitlet om mineraler og bergarter i læreboken. Disse termene ble så diskutert i klassen, og mange gjenstander ble tatt i bruk for å forklare og tydeliggjøre. Først mot slutten av økta på to timer ble læreboken brukt, og da leste elevene gruppevis deler av kapitlet og skrev korte tekster og notater. Med et høyt antall minoritetskulturelle elever i klassen viste det seg gunstig å spille på de ulike kulturelle bakgrunnene som elevene representerte og sammenholde disse med den norske konteksten før læreboken ble studert. Kapitlet om geologi var for eksempel illustrert med et bilde av Frognerparken, og det kom for en dag at mange av elevene ikke forbandt noe med bildet. Der læreboken hadde utydelige illustrasjoner og manglende kategoriseringer av bergarter og mineraler, kunne datamediet være til verdifull hjelp for supplerende forklaringer og tydeliggjøringer. Rent visuelt byr dette mediet på større variasjon i eksempler og forklaringer enn læreboken evner å gjøre i tillegg til at bildematerialet har en bedre skarphet (oppløsning) og mer optimal fargegjengivelse. Helt til sist i økta ble elevene bedt om å gå ut i skolegården for å samle små steiner. Økta ble avsluttet med forskjellige typer oppgaver som skulle løses fram mot neste økt: én gruppe skulle gå til datarommet og søke opp spesifikk informasjon om geologi, en annen gruppe skulle ordne de steinene som var blitt funnet i skolegården, en tredje gruppe skulle skrive en fortelling om steiner osv. (Se Askeland \& Aamotsbakken, 2010).

I dette klasserommet måtte elevene lese, skrive, bruke muntlig språk og tegne. Geologiøkta representerer lese- og skrivehendelser som vi vil hevde karakteriseres av at grunnleggende begrepsforståelse trenes ved hjelp av lesing og skriving. Lærerens tilretteleggende rolle er tydelig, og muntlig bruk av språket spilte en stor rolle. Både førlesingsstrategiene som læreren brukte, og det etterfølgende arbeidet i smågrupper, var gjennomtenkt og vel forberedt. Gruppeinndelingen hvilte på et prinsipp om at alle elevene i klassen skulle få både utfordringer og nødvendig støtte. De fleste elever i klassen brukte Internett i oppgaveløsning på skolen, men dette tilførte ikke annet enn at de fant alternative illustrasjoner og ekstra forklaringer. De tradisjonelle læremidlene, som lærebøker, spilte mindre rolle i arbeidet med geologiemnet, men var et utgangspunkt for lærerens tilrettelegging for forståelse av begreper om emnet mineraler og bergarter. Vi kan derfor hevde at læreboken fungerte som kilde for læreren og som støtte for elevene i arbeidet med emnet. Selve lærebokteksten var heller mager med hensyn til forklaringer om sentrale begreper i faget. Boken 
ville neppe kunne stå på egne bein uten lærerens hjelp, noe vi fikk bekreftet gjennom intervju med elever om den aktuelle teksten. I det observerte læringsarbeidet spilte lesing av læreboktekst dermed en mindre rolle enn samtale om begreper og skriving i oppgaveløsning. Med andre ord kan vi snakke om en triangulering av lesing, skriving og muntlighet i dette tilfellet, der muntlig tilrettelegging fungerte som en forutsetning for oppøving i literacy.

\section{Literacy i et fysikklasserom i videregående skole}

Elevene i denne klassen hadde hatt faget Fysikk 1 forrige skoleår og var i gang med Fysikk 2; kurs som regnes som avansert og krevende. Vi har fått godt innsyn i elevenes og også lærernes syn på fagets krav, muligheter og hvordan undervisningen kan gjøres mest mulig optimal gjennom de nevnte videoobservasjonene og fokusgruppeintervjuene. Vi har konsentrert oppmerksomheten mye om hvordan elever bruker kilder for å løse sine ulike oppgaver i faget.

Elevene skulle lære om Einsteins spesielle relativitetsteori. Læreren hadde gjort en grundig forberedelsesjobb, og klassen virket motivert for emnet. Elevene arbeidet med læreboken og nettstedet som var knyttet til denne (Lokus). Vi observerte at en rekke andre læringsressurser ble brukt som for eksempel arbeidsbøker, leksika på nett og i papirform, overhead-projektor og vanlig tavle. Elevene leste, skrev, samtalte og arbeidet sammen i par eller smågrupper; noen også individuelt. En dominerende modalitet var representert ved lærebokens brødtekst (fagteksten), illustrasjoner som fotografier, modeller og grafer, forklaringer, oppgaver og øvelser. Digital teknologi som pc tjente som redskap, og de potensielle modalitetene som pc-en byr fram som tre-dimensjonale tegneprogram, grafikk og muligheter for konkretisering av abstrakte fenomener ved hjelp av modeller, ble også benyttet i noen grad. Både den tradisjonelle læreboken og pc-en byr til sammen fram muligheter for en multimodal og multimedial læringssituasjon som både er kompleks og utfordrende for elevene. Likevel kan vi fastslå at de digitale mediene fungerte som hjelperessurser fordi de gav en rikere informasjonstilgang og muligheter for tredimensjonalitet.

Undervisningen i Einsteins spesielle relativitetsteori utgjorde lese- og skrivehendelser (literacy events) som var sammensatte fordi det foregikk mange parallelle aktiviteter med bruk av en rekke læringsressurser. Ved hjelp av videofilming og feltnotater observerte vi at læreren startet med å minne elevene om dagens tema og relaterte til den forrige undervisningsøkta. Han foreleste så om emnet ved å bruke tavle og kritt og ved å vise lysark med tegninger og håndskrevne forklaringer av fenomener knyttet til relativitetsteorien. Det viste seg at disse medieringsredskapene var svært nyttige for elevenes læring. Under sine forklaringer var læreren hele tiden oppmerksom overfor elevene og så til at de fikk med seg hans poenger. Han så ofte på dem, stilte spørsmål og gav små 
kommentarer. Om han ble i tvil om de helt hadde forstått, gjentok han poenget eller forklaringen. Han spurte for eksempel: "Er dere med nå?” Elevene nikket bekreftende, og på denne måten ble vi vitne til det en kan kalle dialogen i lærermonologen (Askeland, 1997). Læreren fortsatte med å stille spørsmål og utfordret elevene til å forklare teorien. Han bad enkelte av elevene om å komme opp til tavla for å gi delforklaringer enten muntlig eller i kombinasjon med utregninger og tegning av modeller. Når han gjorde dette, hadde han strøket ut sine egne tavleforklaringer med den hensikt å la elevene gjenta forklaringene han hadde gitt.

En svært talentfull elev gikk opp til tavla for å vise de andre hvordan han har regnet en oppgave som dreier seg om lysets hastighet. Eleven skrev først sin løsning ganske raskt og brukte nesten hele tavla for å få med alle leddene i utregningen. Deretter gikk han tilbake til første ledd i utregningen og gikk detaljert gjennom alle ledd mens han brukte fagbegreper fra fysikken. Læreren kommenterte elevens bruk av formler og påpekte at det også ville ha vært mulig å bruke andre formler for å regne ut det han kalte "lysfarta". Det vi her observerte var en demonstrasjon av matematisk literacy som foruten selve utregningen var avhengig av lesing, skriving og muntlig bruk av språket.

Mot slutten av økta måtte elevene gjøre et laboratorieeksperiment og skrive en laboratorierapport med detaljerte forklaringer om formålet med eksperimentet, prosessen og resultatene av den. I denne prosessen skrev elevene det Kolstø benevner som en prosedyretekst med beskrivelser av hvordan eksperimentet ble utført, hva slags utstyr som ble anvendt og hvordan de forskjellige trinnene i eksperimentet forløp. De leverte senere rapporter til læreren for vurdering, noe som etter Kolstøs terminologi kan karakteriseres som eksperimentrapporter (Kolstø, 2009). Under eksperimentet observerte vi at grunnleggende ferdighet muntlighet var svært viktig. Denne ferdigheten blir ofte tatt for gitt og ikke viet så stor oppmerksomhet (Penne \& Hertzberg, 2008). Læreren assisterte og forklarte løpende samtidig som han utfordret spesielle elever til å hjelpe til og støtte andre som ikke arbeidet fullt så raskt. Han forklarte hele tiden hvorfor han la vekt på spesielle sider ved eksperimentet som knyttet seg til relativitetsteorien. Det hadde med lysets hastighet å gjøre.

Muntlighet har en stor plass i fysikkfaget, både i ordinær undervisning og forsøk i klasserommet. Tekstkulturen i faget viser knappe tekster med stort innslag av fagtermer, formler, illustrasjoner, kurver, grafer etc. De korte brødtekstene er ofte knyttet til oppgaver med korte instruksjoner der elevene oppfordres til å utføre eksperimenter og levere skriftlige rapporter. Knappheten og komprimeringen tilsier at muntlig behandling av stoffet fra læreren må til for å skape forståelse og dermed læring. Vi så mange eksempler på samarbeid i grupper eller to og to, og det var ikke uvanlig at elever leverte felles rapporter, noe som ble godtatt og verdsatt av læreren. Læreren så på rapportene som en form for loggskriving, der elevene minte seg selv på hva forsøket gikk ut på og hva som var meningen med det. Terskelen var derfor lav for denne typen 
skriving, men læreren var opptatt av å gi elevene tilbakemelding på rapportene og etterlyste ofte mer tekst fra elevenes side: "Da skriver jeg bare TEKST? i margen, og da skjønner de hva jeg mener. Jeg forklarer dem at dette må de gjøre for sin egen skyld, for det er synd om de ikke skulle huske hvilke forsøk de selv har gjort når de kommer opp til eksamen.” Lærerens insistering på at elevene skulle skrive forklaringer til sine utregninger og eksperimenter, understreker vårt poeng om at matematisk literacy også inkluderer lesing og skriving. Loggskriving som læreren definerte rapportene som, er en refleksjonstekst som nettopp sier hva som er gjort, gangen i for eksempel et eksperiment og resultatet til slutt. Slik skriving har bakgrunn i lesing av fagtekster, lærerens forklaringer og diskusjoner med medelever. Fysikk er ikke bare tall og formler, men også tekst som fordrer literacy-kompetanse både hos elevene og læreren som legger til rette.

Noen ganger kunne forbindelsen mellom lesing og skriving bli noe tett, som i tilfeller der eleven kopierte oppgaveteksten, som regel en "oppskrift" på et eksperiment fra den digitale læringsressursen og brukte den som grunnlag for sin egen rapport. I slike tilfeller kunne vi se at eleven brukte identiske ord og setningsstrukturer fra læringsressursen, og bare fylte inn med egne data, uten å endre det som nødvendigvis må endres for at teksten skulle bli en rapport. Et eksempel på dette var når læringsressursens tekst hadde pronomenet “du”, og eleven glemte å skrive "jeg” for å bekrefte at vedkommende hadde utført eksperimentet. Slik sett hadde eleven klippet og limt og skrevet inn egne resultater uten tanke på at teksten skulle leses som tekst.

\section{Sammenlikning av de to klasserommene}

Det finnes visse likheter mellom de to klasserommene selv om alderen på elevene er svært ulik. Blant likhetene er at lesing og skriving er uløselig knyttet sammen og foregår med samtidighet. Elevene skriver under lesing og leser under skriving. Videre spiller læreren en betydningsfull rolle i begge klasserom der muntlige ferdigheter kommer i spill. I naturfagsklasserommet i femteklasse viste læreren seg som viktig for å forberede elevene på emnet via introduksjon av og samtale om fagbegrep og utnyttelse av erfaringskunnskap. I fysikkklasserommet var læreren viktig for å gi klare råd og supplerende forklaringer.

Bruken av lærebøker og andre læremidler spilte i begge klasserom støtteroller. Det var i begge tilfeller naturfaglige og fysikkfaglige begreper som nok stod forklart i lærebøkene, som stod i sentrum i øktene. Det var likevel lærerens utlegninger og tolkninger som var avgjørende for elevenes læring og engasjement. Lærebøkene kan sies å spille en rolle for læring, og enkelte forskere har pekt på at de til og med spiller en dominerende rolle (Klette, 2004; Skjelbred, 2010). Vi mener at i våre case fungerer lærebøkene og de andre læremidlene først og fremst som kilde for lærerens undervisning. De må med 
andre ord suppleres ved muntlige og skriftlige forklaringer. Lærebøkene og arbeidsbøkene kan betraktes som basiselementer som skaffer elever kunnskap og gir rom for repetisjoner og innøving, men de fungerer ikke optimalt uten lærerens tilrettelegging.

Flere forskere har pekt på at digitale medier brukes i stadig økende grad i skolen. De samme forskerne har ment at mediene betyr effektivitet i læringssituasjonen (Byron, 2008; Buckingham, 2007). Våre case har vist at digitale medier kan fungere som støtte og gi muligheter for rask informasjonsinnhenting. Særlig var dette tilfelle i videregående skole. Likevel vil vi hevde at det å slå opp i en bok, et leksikon eller studere emnehefter kunne gi samme informasjon og føre til samme læringseffekt i samarbeid med lærerens undervisning.

\section{Avslutning}

I denne artikkelen har vi stilt spørsmålet om hvilken rolle lesing og skriving spiller for utviklingen av naturfaglig literacy (scientific literacy), og vi har hevdet at lesing og skriving kan studeres som én kompleks ferdighet. Videre har vi argumentert for lærerens betydning som modell og mediator for utvikling av literacy i de to fagene.

Vi har sett at lesing og skriving er sammenknyttede ferdigheter i en grad som gjør at det er naturlig å tale om én samlet ferdighet, her oftest omtalt som literacy. Dette er ikke bare basert på observasjon av didaktiske valg som læreren har foretatt, men på observasjon av hva elever faktisk gjør når de leser og skriver. Optimal opplæring i literacy er imidlertid svært avhengig av muntlig ferdighet, og dette går tilbake til lærerens viktige rolle som modellerer og mediator. Klasseromsdialogen og samarbeidet støttet av læringsressurser på papir og skjerm er viktige elementer for at trianguleringen lesing-skrivingmuntlig bruk av språket skal fungere mest mulig optimalt. I våre studier har vi sett at bruk av den tradisjonelle læreboken og digital teknologi varierer i betydning når det gjelder oppbygging av literacy-kompetanse. Det er ikke særlig overraskende at det brukes mer teknologi i videregående opplæring enn i grunnskolens lavere klasser.

Vi har tidligere studert hvordan lærebøker og andre læremidler legger til rette for god lesing og skriving. Prosjektene våre har vist at lærebøkene fungerer som supplement til undervisningen både i grunnskolen i videregående opplæring. De er kilder som læreren henter stoff fra, og de er støttemateriell for elevene når de skal løse oppgaver og gå tilbake for å repetere lærerens forklaringer (Skjelbred \& Aamotsbakken, 2010; Smidt, Seip Tønnessen \& Aamotsbakken, 2011). Selv gode lærebøker og læremidler trenger en aktiv og utfyllende lærer som modellerer det som skal læres og går ut over lærebokens tekster. At læreren er "vendt tilbake" i forskningslitteraturen, er påtakelig etter perioder der ansvar for egen læring og mer selvstendige læringsaktiviteter har hatt status. Funn fra våre 
prosjekter støtter den nyere forskningen på betydningen av lærerens rolle (Askeland \& Aamotsbakken, 2010; Danielsson, 2011; Reichenberg, 2008, 2012). Funn motsier i noen grad tidligere forskning på lærebøker og læremidler som har lagt stor vekt på fagteksters kvalitet og iboende muligheter for læring. Vi har funnet at læremidlene er viktige, men at det er lærerens utlegging og valg som har mest å bety.

At læreren er en nøkkelperson når det gjelder å bygge opp literacykompetanse hos elevene, bekreftes også av andre studier (jf. Molander \& Terum, 2008; Nordahl, 2010; Hattie, 2009). Det er læreren som legger til rette og inspirerer til læring, og det er han eller hun som gir råd om kildebruk enten det er i form av lærebok eller nettressurser. I dette tilfellet er læreren en viktig læringsressurs, også etter elevens oppfatning, slik disse kommer til uttrykk i intervjuer.

Vi har i en tidligere artikkel pekt på lærerens viktige rolle som leselærer i grunnskolen, der det legges til rette for læring før, under og etter lesing (Askeland \& Aamotsbakken, 2010). Våre observasjoner fra fysikkfaget i videregående skole viser at lærerens rolle som leselærer ikke blir mindre viktig med årene, slik en kanskje kunne vente, elevenes alder tatt i betraktning. Det arbeides med å erobre fagspråket både muntlig og skriftlig, og samtaler og tekster inngår i et større kretsløp der målet er læring. Vi har sett at det arbeides med grunnleggende ferdigheter for å erobre fagets sjangrer og legge til rette for læring (jf. Kolstø, 2009; Knain \& Kolstø, 2011; Ødegaard \& Frøyland, 2010; Maagerø \& Skjelbred, 2010). Skriftlige sjangrer spiller en stor rolle, men også muntlige aktiviteter er av stor betydning i klasserommene vi har besøkt, både i grunnskole og videregående opplæring.

Våre prosjekter har vist at læring foregår multimodalt og multimedialt, og at det er nødvendig med en kombinasjon av ferdigheter for å tilegne seg literacykompetanse. Lesing, skriving, noe bruk av digital teknologi og ikke minst muntlig språk spiller sammen slik at det er naturlig å vise til Gunther Kress' term multi-literacy (Kress, 2003, 2010). I tillegg kommer grunnleggende ferdighet regning (matematisk literacy) i tilfellet med fysikk-klasserommet. Også våre intervjuer med elever enten i par eller i fokusgrupper (Kvale \& Brinkmann, 2009) har vist at samtlige fem ferdigheter eller kompetanser er viktige for læringsprosessene, men at noen ferdigheter er overordnet andre. Dette bekrefter betydningen av OECDs vektlegging av de fem nøkkelkompetansene som er implementert i det norske planverket (DeSeCo, 2005). Våre observasjoner og intervjuer har også vist at flere ferdigheter må ses i sammenheng, og særlig observasjoner fra fysikk-klasserommet har gitt eksempler på nettopp det. Fysikkelevenes laboratorierapporter har vist at alle fem ferdigheter spiller sammen i utformingen. I rapportene spores en klar linje fra emnet som ble introdusert av læreren og som fant gjenklang i lærebokens fagstoff via lærerens forklaringer, selve eksperimentet som elevene utførte fram til de skrev ned, tegnet og forklarte hva de hadde utført (Kolstø, 2009). 
Våre observasjoner fra fysikk-klasserommet og også fra naturfagsklasserommet på femte trinn har gitt eksempler på at tekster både er blitt satt i bevegelse (Liberg, 2004) og at elevene har kunnet bevege seg i tekster. De har gitt oss eksempler på veksling mellom medier, modaliteter og tekster og vist stor evne til å handle kombinatorisk for et best mulig resultat. Men de viser også at det kan være hårfine grenser mellom det å være en god skriver og det å plagiere andres tekster, særlig i sjangrer som komponeres etter “oppskrift”, som i laboratorieøvelser i fysikk, der "svaret” er viktigere enn teksten.

Kompetansekrav og betydningen av å beherske flere typer literacy følger dagens unge fra de går i barnehagen til de entrer forskjellige posisjoner i profesjonslivet. Å beherske grunnleggende ferdighet lesing og skriving (literacy) er en forutsetning for meningsfull deltakelse i samfunnet, både i yrkessammenheng og på fritiden. I tillegg kommer betydningen av å ha tilegnet seg fagrelatert literacy som den som preger naturfag, når man skal forstå prosesser i naturen og universet.

\section{Referanser}

Adler, P.A. \& Adler, P. (1994). Observational Techniques. I N.K. Denzin \& Y.S. Lincoln (red.), Handbook of Qualitative Research. ( 377-392). Thousand Oaks, CA.: Sage Publications.

Askeland, N. (1997). Den pedagogiske teksten som møteplass. Dialogisitet i lærarens munnlege fagtekst: erfaringar frå eit forprosjekt. I E.B. Jacobsen, (red.), Forskningsdagene 97: en tverrfaglig artikkelsamling basert på tretten foredrag. Tønsberg: Høgskolen i Vestfold. http://www-bib.hive.no/tekster/hveskrift/notat/1997-3/a1.html

Askeland, N. \& Vareberg.O. (2010). Kvalitet i læeremidler etter oppheving av godkjenningsordningen. Foredrag for Nettverk for skolebibliotek og læremidler. Gardermoen 28.5.2010.

Askeland, N. \& Aamotsbakken B. (2010). Læraren som leselærar. I Norsk pedagogisk tidsskrift nr 3, 256-266.

Bakhtin, M. (1981).The dialogical imagination. I P. Morris (red.), The Bakhtin reader: selected writings of Bakhtin, Medevedev and Voloshinov . (74-81). New York: Oxford University Press.

Bakken, A. (2009). Retorikk i skolen. Oslo: Universitetsforlaget.

Barton, D. (1994). Literacy. An Introduction to the Ecology of Written Language. Oxford: Blackwell.

Barton, D. \& Hamilton, M. (1998). Local Literacies: Reading and Writing in One Community. London: Routledge.

Barton, D., Hamilton, M. \& Ivanic; R. (2000). Situated Literacies. Reading and Writing in Context. London \& New York: Routledge.

Bazerman,C. \& Prior, P.A. (2004). Introduction. I C. Bazerman \& P.A. Prior (red.), What writing does and how it does it: an introduction to analyzing texts and textual practices. (1-10). Mahwah, NJ: Lawrence Erlbaum. 
Beetham, H. \& Sharpe, R. (2007) An introduction to rethinking pedagogy for a digital age. I H. Beetham \& R. Sharpe (red.). Rethinking pedagogy for a digital age: Designing and delivering e-learning. London: Routledge.

Berge, K. L. (2005). Skriving som grunnleggende ferdighet og som nasjonal prøve - ideologi og strategier. I A. J. Aasen \&N.S. Nome (red.), Det nye norskfaget.(161 - 189). Bergen: LNU/Fagbokforlaget.

Berge, K. L. (2012). Retorisk dannelse som grunnlag for demokratisk medborgerskap i skolen: om de grunnleggende ferdighetene skriving og muntlighet i Kunnskapsløftet. I K.L. Berge \& J.H. Stray(red.), Demokratisk medborgerskap i skolen ( 79-101). Bergen: Fagbokforlaget.

Berners-Lee, T. (1999). Weaving the web: The past, present and future of the worldwide web by its inventor. London: Orion.

Blatter, J. \& Blume, T. (2008). In Search of Co-variance, Causal Mechanisms or Congruence?: Towards a Plural Understanding of Case Studies. Swiss Political Science Review 14(2), 115-56.

Bråten, I. (red.) (2007). Leseforståelse. Lesing i kunnskapssamfunnet - teori og praksis. Oslo: Cappelen akademisk.

Buckingham, D. (2007). Beyond Technology; Children's Learning in the Age of Digital Culture. London: Polity Press.

Burn, A. (2009). Making new media. New York: Peter Lang.

Byron, T. (2008). Safer children in a digital world. London: DCSF.

Cerratto-Pargman, T. \& Wærn, Y. (2003). Appropriating the use of a Moo for collaborative learning. Interacting with Computers, 15, 759-781.

Cokely, E. T., Galesic, M., Schulz, E., Ghazal, S., \& Garcia-Retamero, R. (2012). Measuring Risk Literacy: The Berlin Numeracy Test. Judgement and Decision Making, Vol. 7; No. 1, January 2012, 25-47.

Cope, B. \& Kalantzis, M. (2000). Introduction: Multiliteracies. I B. Cope \& M. Kalantzis (red.), Multiliteracies: Literacy learning and the design of social futures. London: Routledge

Cummins, J. (2004). Multiliteracies Pedagogy and the Role of Identity Texts. I K. Leithwood, P. McAdie, N. Bascia \& A. Rodigue (red.), Teaching for Deep Understanding: Towards the Ontario Curriculum That We Need. (68-74). Toronto: Ontario Institute for Studies in Education of the University of Toronto and the Elementary Federation of Teachers of Ontario.

Danielsson, K. (2011). ”Då blir de fulla och glada” - multimodala representationer av atommodellen i kemiklassrum. I J. Smidt, E. Seip Tønnessen \& B. Aamotsbakken (red.), Tekst og tegn. Lesing, skriving og multimodalitet i skole og samfunn. (121-145). Trondheim: Tapir Akademisk Forlag.

Davies, J. and Merchant, G. (2009). Web 2.0 for schools: Learning and social participation. New York: Peter Lang.

DeSeCo (2005). The definition and selection of key competencies. Lastet ned 27.02.2012 fra http://www.oecd.org/dataoecd/47/61/35070367.pdf

Drotner, K. (1999). Unge, medier og modernitet - pejlinger i et foranderligt landskab. København: Borgen/Medier.

Engebretsen, M. (2007). Digitale diskurser. Nettavisen som kommunikativ flerbruks-arena. Kristiansand: Høyskoleforlaget.

Engen, T.O. \& Kulbrandstad, L.I. (2004). Tospråklighet, minoritetsspråk og minoritetsundervisning. Oslo: Gyldendal Akademisk.

Eriksson, Y. (2009). Bildens tysta budskap. Interaktion mellan bild och text. Stockholm: Norstedts Akademiska Förlag. 
Hattie, J. (2009). Visible learning: a synthesis of over 800 meta-analyses relating to achievement. London: Routlegde

Hertzberg, F. (1988). Amerika! Eller en sjuårings veg til skriftspråket. I F. Hertzberg Vagle, W. \& Spurkland, T. (red.), I klartekst: festskrift til Bernt Fossestøl på 60-årsdagen 30. juli 1988. (155-177). Oslo: Novus.

Hvistendahl, R. (2001). Elevportretter. Fra det flerkulturelle klasserommet. Oslo: Universitetsforlaget.

Hvistendahl, R. (2007). Unge lesere fra språklige minoriteter. I I. Bråten (red.), Leseforståelse. Lesing i kunnskapssamfunnet - teori og praksis. (147-167). Oslo: Cappelen Akademisk.

Hvistendahl, R. (red.). (2009). Flerspråklighet i skolen. Oslo: Universitetsforlaget.

Hvistendahl, R. \& Roe, A. (2004). The Literacy Achievement of Norwegian Minority Students. Scandinavian Journal of Educational Research. Vol. 48, No. 3. July 2004, 307-324.

Kjeldsen, J. (2006). Retorikk i vår tid: en innføring i moderne retorisk teori. Oslo: Spartacus.

Kjeldsen, J. E \& Grue, J. (2011). Scandinavian studies in rhetoric: Retorikförlaget.

Klette, K. (2004). Fag og arbeidsmåter i endring?: tidsbilder frå norsk grunnskole. Oslo:Universitetsforlaget.

Knain, E. \& Kolstø, S.D. (red.) (2011). Elever som forskere i naturfag. Oslo: Universitetsforlaget.

Kolstø, G. (2009). Vektlegging av lesing i naturfaget. NorDiNa 5, 5-88.

Kress, G. (2010): Multimodality. A social semiotic approach to contemporary communication. London: Routledge.

Kress, G. (2003). Literacy in the new media age. London: Routledge.

Kress, G. \& van Leeuwen, T. (1996). Reading Images. The grammar of visual design. London \& New York: Routledge.

Kress, G. \& van Leeuwen, T. (2001). Multimodal Discourse: The Modes and Media of Contemporary Communication. London: Edward Arnold.

Kress, G., Jewitt, C., Ogborn, J. \& Tsatsarelis, C. (2001). Multimodal teaching and learning: the rhetorics of the science classroom. London: Continuum.

Kulbrandstad, L.I. (2003). Lesing i utvikling. Teoretiske og didaktiske perspektiver. Bergen: Fagbokforlaget/LNU.

Kvale, S. \& Brinkmann, S. (2009). Interviews. Learning the craft of qualitative research interviewing. Thousand Oaks, CA: Sage Publications.

Lankshear, C. \& Knobel, M.(2006). Digital Literacy and Digtial Literacies. Digital kompetanse 1, 12-24.

Lemke, J.L. (2000). Multimedia literacy demands of the scientific curriculum. Linguistics and Education, 10(3), 247-271.

Liberg, C. (2004). Rörelse i texter, texter i rörelse. I I. Bäcklund, U. Börestam, U.M. Marttala \& H. Näslund (red.), Text i arbete/Text at work. Festskrift till Britt-Louise Gunnarsson, den 12 januari 2005. (106-114). Uppsala.

Lorentzen, R.T. (2002). ”Til pappa og mamma fra Ingrid”- om det første barn skriv. I I. Mjør, (red.), Kulturbarnehagen. Oslo: Samlaget.

Løvland, A. (2006). På mange måtar. Samansette tekstar i skolen. Bergen: Fagbokforlaget.

Madssen, K.A. (1999). Morsmålsfagets normtekster: et skolefag blir til - norskfaget mellom tradisjon og politikk. Trondheim: Norges teknisk-naturvitenskapelige universitet.

Molander, A \& Terum, L.I. (2008). Profesjonsstudier. Oslo: Universitetsforlaget.

Maagerø, E. \& Skjelbred D. (2010). De mangfoldige realfagstekstene - om lesing og skriving i matematikk og naturfag. Bergen: Fagbokforlaget 
Nordahl, T. (2010). Eleven som aktør. Fokus på elevens dannelse og handlinger $i$ skolen.Oslo: Universitetsforlaget.

Norris, S.P. \& Phillips, L.M. (2003). How Literacy in its fundamental sense is central to scientific literacy. Science Education 87, 224-240.

Otnes, H. (red.) (2009). A være digital i alle fag. Oslo: Universitetsforlaget.

Penne, S. (2001). Norsk som identitetsfag - norsklæreren i det moderne. Oslo: Universitetsforlaget.

Penne, S. \& Hertzberg, F. (2008). Muntlige tekster i klasserommet. Oslo: Universitetsforlaget.

Postholm, M.B. (2005). Kvalitativ metode. En innføring med fokus på fenomenologi, etnografi og kasusstudier. Oslo: Universitetsforlaget.

Postholm, M.B. \& Moen, T. (2009). Forsknings- og utviklingsarbeid i skolen. En metodebok for lærere, studenter og forskere. Oslo: Universitetsforlaget.

Pressley, M. (2005). Reading Instruction That Works. Third Edition. The Case for Balanced Teaching (Solving Problems in the Teaching of Literacy. New York: Guilford Press.

Reichenberg, M. (2008). Vägar till läsförståelse: texten, läsaren och samtalet. Stockholm: Natur och kultur.

Reichenberg, M. (2012), Texter, läsförståelse och läsundervisning i Norge och Sverige - en översikt. Acta Didactica, Vol 6, Nr. 1, Art. 3.

Selander, S. \& Kress, G. (2010). Design för lärande - ett multimodalt perspektiv. Stockholm: Norstedts.

Sjøberg, S. (2009 [2004]). Naturfag som allmenndannelse: en kritisk fagdidaktikk. Oslo: Gyldendal Akademisk.

Skaftun, A. (2006). Å kunne lese. Grunnleggende ferdigheter og nasjonale prøver. Bergen: Fagbokforlaget/LNU.

Skaftun, A. (2009). Litteraturens nytteverdi. Bergen: Fagbokforlaget.

Skjelbred, D. \& Aamotsbakken, B. (red.) (2010). Lesing av fagtekster som grunnleggende ferdighet. Oslo: Novus forlag.

Skjelbred, D. (2010). Lesing og skolens fagtekster i en historisk kontekst. I D. Skjelbred \& Aamotsbakken, B. (red.), Lesing av fagtekster som grunnleggendeferdighet. (35-59). Oslo: Novus forlag.

Smagorinsky, P. (1994). Speaking about writing: Reflections on research methodology. Thousand Oaks, CA: Sage Publications.

Smidt, J. (2011). Ti teser om skriving i alle fag. I J. Smidt, R. Solheim, R. \& A.J. Aasen (red), På sporet av god skriveopplcring. (9-43). Trondheim: Tapir Akademisk Forlag.

Smidt, J. (red.) (2010). Skriving i alle fag - innsyn og utspill. Trondheim: Tapir Akademisk Forlag.

Smidt, J., Seip Tønnessen, E. \& Aamotsbakken, B. (2011). Tekster i bevegelse: Tekster, tegn og grunnleggende ferdigheter. I J. Smidt, E. Seip Tønnessen \& B. Aamotsbakken (red.), Tekst og tegn. Lesing, skriving og multimodalitet i skole og samfunn. (7-35). Trondheim: Tapir Akademisk Forlag.

Snow, C. P. (1959). The two cultures and the scientific revolution. Cambridge: Cambridge University Press.

Snow, C. P. (1964). The two cultures: and A second look: an expanded version of the two cultures and the scientific revolution. Cambridge: Cambridge University Press.

Stake, R.E. (1995). The Art of Case Study Research. Thousand Oaks, CA.: Sage Publications.

Steen, G. J. (2011). The Contemporary Theory of Metaphor - now new and improved!. Review of cognitive linguistics, 9(1), 26-64.

Swales, J. (1990). Genre analysis: English in academic and research settings. Cambridge: Cambridge University Press. 
Swales, J. (1998). Other floors:other voices: a textography of small university building. Hillsdale, NJ: Lawrence Erlbaum.

Säljö, R. (2006). Lœring og kulturelle redskaper: om læreprosesser og den kollektive hukommelsen. Oslo: Cappelen akademisk forlag.

Sørensen, B.H., Audon, L. \& Levinsen, K.T. (2010). Skole 2.0. Århus: Forlaget Klim.

Tønnessen, E.S. (2010). Sammensatte tekster: barns tekstpraksis. Oslo: Universitetsforlaget.

Vagle, W., Sandvik, M. \& Svennevig, J. (1993). Tekst og kontekst: en innføring i tekstlingvistikk og pragmatikk. Oslo: Cappelen.

Vannini, P. (red.) (2009). Material culture and technology in everyday life: Ethnographic approaches. New York: Peter Lang.

Ødegaard, M. \& Frøyland, M. (2010). Undersøkende naturfag ute og inne: Forskerføtter og leserøtter. Kimen, nr. 1. Oslo: Naturfagsenteret.

Aamotsbakken, B. \& Knudsen, S.V. (2011). A tenke teori. Om leseteorier og lesing. Oslo: Gyldendal Akademisk.

Aase, L. (2005a). Norskfaget - skolens fremste danningsfag. I K. Børhaug, A.-B. Fenner \& L. Aase (red.). Fagenes begrunnelser. Skolens fag og arbeidsmåter i danningsperspektiv. (69-83). Bergen: Fagbokforlaget.

Aase, L. (2005b). Skolefagenes ulike formål - danning og nytte. I K. Børhaug, A.-B. Fenner \& L. Aase (red.), Fagenes begrunnelser. Skolens fag og arbeidsmåter $i$ danningsperspektiv. (15-28). Bergen: Fagbokforlaget.

${ }^{1}$ Også i Sverige har termen literacy blitt debattert, og Olle Josephson har forsøkt seg med en rekke omskrivninger av begrepet til svensk som lese- og skrivekyndighet, skrivekultur o.a. Også Roger Säljö har på samme måte diskutert begrepet og nøyet seg med å fastslå at det kan benevner som "skriftspråklige aktiviteter" er i sin natur komplekse og varierte (Säljö, 2005, s. 208).

${ }^{2}$ I artikkelen «Measuring Risk Literacy: The Berlin Numeracy Test» defineres numeracy slik: "The more basic level of numeracy are concerned with the real number line, time, measurement, and estimation.” Artikkelen diskuterer også flere nivåer av numeracy (Cokely, Galesic, Schulz, Ghazal \& Garcia-Retamero, 2012, s. 25). 